\title{
Activity of acyclic halogenated tubercidin analogs against human cytomegalovirus and in uninfected cells
}

\author{
M. Reza Nassiri' ${ }^{1}$, Steven R. Turk ${ }^{1}$, Gary M. Birch ${ }^{1}$, Lisa A. Coleman', \\ Jerry L. Hudson ${ }^{2}$, Jeffrey S. Pudlo ${ }^{3}$, Leroy B. Townsend ${ }^{3}$ and \\ John C. Drach ${ }^{1}$ \\ ${ }^{1}$ Department of Biologic and Materials Sciences, School of Dentistry, ${ }^{3}$ Interdepartmental Program in \\ Medicinal Chemistry, College of Pharmacy, The University of Michigan, Ann Arbor, Michigan and \\ ${ }^{2}$ Beckton Dickenson Immunocytometry Systems, San Jose, California, U.S.A.
}

(Received 7 May 1990; accepted 21 August 1990)

\section{Summary}

Novel acyclic halogenated tubercidins (4-amino-5-halo-7-[(2-hydroxyethoxy)methyl]pyrrolo[2,3-d]pyrimidines) were examined for their ability to inhibit human cytomegalovirus (HCMV) in yield reduction assays. 5-Bromo acyclic tubercidin (compound 102) was a more potent inhibitor of virus replication than the chloro- and iodo-substituted analogs (compounds 100 and 104). At a $100 \mu \mathrm{M}$ concentration, the bromo and chloro compounds were more potent than acyclovir but not ganciclovir. Virus titers were reduced more than $99 \%$ by compounds 102 and 104 whereas compound 100 and the equally potent acyclovir reduced titers by only $90 \%$. Quantitation of viral DNA by DNA hybridization demonstrated strong inhibition of HCMV DNA synthesis by these compounds. The most potent inhibitor, compound 102 , had a $50 \%$ inhibitory $\left(\mathrm{I}_{50}\right)$ concentration $(1.6 \mu \mathrm{M})$ comparable to that of ganciclovir $(1.8 \mu \mathrm{M})$. Cytotoxicity in uninfected human cells was evaluated and revealed the following: cell growth rates slowed markedly in the presence of $10 \mu \mathrm{M}$ compound 102 whereas the same concentration of compounds 100 and 104 led to only a slight prolongation of population doubling time; these compounds inhibited cellular DNA synthesis but not RNA or protein synthesis, as measured by incorporation of radiolabeled precursors into acid-precipitable macromolecules; flow cytometry indicated that compound 102 was a mid-S phase blocker, and adenosine antagonized the inhibition of $\left[{ }^{3} \mathrm{H}\right] \mathrm{d}$ Thd incorporation by compound 102 .

Correspondence to: J.C. Drach, University of Michigan, School of Dentistry, Ann Arbor, MI 481091078, U.S.A. 
Together, these results demonstrate that compound 102 is a potent and selective inhibitor of viral and cellular DNA synthesis and that acyclic halogenated pyrrolopyrimidine nucleosides may have therapeutic potential.

Cytomegalovirus; Herpes; 7-Deaza adenosine; Pyrrolopyrimidine; Nucleoside

\section{Introduction}

Immunosuppressed individuals are susceptible to infection by human cytomegalovirus (HCMV); consequently this opportunistic virus is the causative agent of morbidity and mortality in AIDS patients (Jacobson and Mills, 1988; Klatt and Shibata, 1988; Niedt and Schinella, 1985) and other immunocompromised individuals such as bone marrow transplant recipients and renal allograft patients (Betts and Hanshaw, 1977; Bombi et al., 1987; Glen, 1981). Neonates also are susceptible to severe HCMV infections (Mostoufi-Zadeh et al., 1984). Thus, there is an immediate need for non-toxic drugs to treat infections caused by this virus. Although a number of compounds are active against HCMV in vitro (Colacino and Lopez, 1983; Field et al., 1983; Mar et al., 1984; Plotkin et al., 1985), only the acyclic nucleosides ganciclovir (DHPG) and acyclovir and the pyrophosphate analog foscarnet are sufficiently promising for clinical use against certain HCMV infections (Collaborative DHPG Treatment Study Group, 1986; Jacobson and Mills, 1988; Meyers et al., 1988; Morris, 1988; Rosecan et al., 1986; Shepp et al., 1985; Skolnick and Hirsch, 1988). Nonetheless, these compounds suffer from disadvantages of low potency (Meyers et al., 1988), lack of efficacy in certain circumstances (O'Donnell et al., 1987; Shepp et al., 1985), and cytotoxic manifestations in some therapeutic regimens (Morris, 1988; Skolnik and Hirsch, 1988). Thus, there is yet a substantial need to discover more potent and safer drugs to treat HCMV infections.

In our search for novel and more efficacious drugs to treat infections caused by herpesviruses, particularly HCMV, we have found that pyrrolopyrimidine nucleosides are potent inhibitors of HCMV in vitro. Particularly, certain deoxyribosyl and arabinosyl pyrrolo' $[2,3-d]$ pyrimidines have selective antiviral activity against this virus (Turk et al., 1987b). Of these fraudulent nucleosides, ara-sangivamycin, aratoyocamycin, and 2'-deoxysangivamycin had the best antiviral selectivity. Based upon this lead, our group designed and synthesized acyclic analogs of tubercidin, toyocamycin, and sangivamycin (Gupta et al., 1989a,b; Pudlo et al., 1988, 1990; Saxena et al., 1988) with the objective of reducing cytotoxicity and retaining antiviral activity. Five-halogen substituted analogs of tubercidin have shown particularly good activity against HCMV in early investigations (Pudlo et al., 1988, 1990). In the present work, we have expanded the antiviral assessment of some of these novel halogenated acyclic tubercidin analogs against HCMV and have explored the cellular and molecular basis by which these compounds act. 


\section{Materials and Methods}

\section{Chemicals}

The acyclic tubercidin analogs referred to herein as compounds $080,100,102$, and 104 were synthesized in the laboratory of one of us (LBT) as described previously (Saxena et al., 1988; Pudlo et al., 1988). They are, respectively, 4-amino-7[(2-hydroxyethoxy)methyl]pyrrolo[2,3- $d$ ]pyrimidine and its 5-chloro, 5-bromo, and 5-iodo derivatives (Fig. 1). Acyclovir was provided by Burroughs Wellcome Co., Research Triangle Park, NC. Ganciclovir was obtained from Syntex Laboratories, Inc., Palo Alto, CA, through the courtesy of Dr. T. Matthews. [Methyl- $\left.{ }^{3} \mathrm{H}\right]$ thymidine $(40 \mathrm{Ci} / \mathrm{mol}),\left[5-{ }^{3} \mathrm{H}\right]$ uridine $(22 \mathrm{Ci} / \mathrm{mmol}),{ }^{3} \mathrm{H}$-L-amino acid mixture $(273$ $\mathrm{mCi} / \mathrm{mg}),\left[{ }^{32} \mathrm{P}\right] \mathrm{H}_{3} \mathrm{PO}_{4}(\mathrm{Pi} ; 100 \mathrm{mCi} / \mathrm{ml})$, and $\left[\alpha-{ }^{32} \mathrm{P}\right] \mathrm{dCTP}(3048 \mathrm{Ci} / \mathrm{mmol})$ were purchased from ICN Radiochemicals Inc., Irvine, CA. Fetal bovine serum was purchased from Hyclone Laboratories, Inc., Logan, UT. Propidium diiodide was purchased from Calbiochem Corp., La Jolla, CA. RNase 1-A was purchased from Sigma Chemical Co., St. Louis, MO.

\section{Cells and virus}

$\mathrm{KB}$ cells, an established human cell line derived from an epidermal oral carcinoma, were routinely grown in minimal essential medium (MEM) with Hanks salts $[\mathrm{MEM}(\mathrm{H})]$ supplemented with $5 \%$ fetal bovine serum. Diploid cell cultures of human foreskin fibroblasts (HFF) were grown in MEM with Earle salts [MEM(E)] supplemented with $10 \%$ fetal bovine serum. Cells were passaged by conventional procedures by using $0.05 \%$ trypsin and $0.02 \%$ EDTA in a HEPES (N-2-hydroxyethylpiperazine- $\mathrm{N}^{\prime}$-2-ethanesulfonic acid)-buffered salt solution [HBS (Shipman, 1969)]. To increase the likelihood of detecting bacterial or mixed bacterial and mycoplasmal contamination, antibiotics were never used in the routine passage of cells (Hayflick, 1973). Cell lines were screened periodically and were mycoplasma free.

The plaque-purified isolate $\left(\mathrm{P}_{0}\right)$ of the Towne strain of HCMV was a gift of Dr. Mark Stinski, University of Iowa. The preparation of HCMV stocks and the titration of virus were performed as described previously (Turk et al., 1987b).

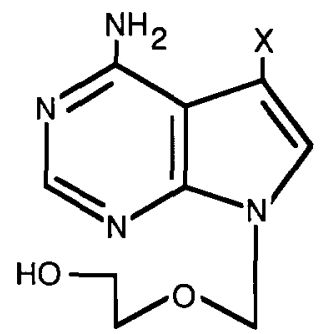

Fig. 1. Structures of the acyclic tubercidin analogs $080(\mathrm{X}=\mathrm{H}), 100(\mathrm{X}=\mathrm{Cl}), 102(\mathrm{X}=\mathrm{Br})$, and $104(\mathrm{X}=\mathrm{I})$. 
The effect of the selected compounds on the replication of HCMV was measured using a titer (yield) reduction assay as we reported previously (Turk et al., 1987b). Briefly, monolayer cultures of HFF cells were infected at a multiplicity of infection of $0.5 \mathrm{PFU}$ per cell and incubated in the presence of test compounds for 7 to 10 days. Following three cycles of freezing at $-76^{\circ} \mathrm{C}$ and thawing at $37^{\circ} \mathrm{C}$, the resulting lysates were diluted and the amount of infectious virus was quantitated on new cultures of HFF cells.

\section{Quantification of viral DNA}

Viral DNA synthesized in HCMV-infected cells was quantitated by DNA-DNA dot blot hybridization procedures as detailed previously (Turk et al., 1987b). Briefly, cultures were infected with 0.5 PFU per cell and incubated with test compounds for seven days. Cultures were harvested and filtered through a Gene Screen membrane (New England Nuclear Corp., Boston, MA). The membrane was hybridized with an E. coli plasmid probe (pACYC-184, obtained through the courtesy of Dr. Stinski) containing a fragment of the HCMV genome which had been nick translated with $\left[{ }^{32} \mathrm{P}\right] \mathrm{dCTP}$. The hybridized label was quantitated using a Beckman model LS 8100 liquid scintillation spectrometer.

\section{Uptake of labeled precursors}

Activity of compounds in uninfected KB cells as well as in HFF cells was determined by measuring the effects of compounds on cellular DNA, RNA and protein synthesis essentially as described previously (Turk et al., 1987b; Birch et al., 1989). Briefly, monolayer cultures were incubated for 18 to $24 \mathrm{~h}$ in the presence of test compounds and either $\left[{ }^{3} \mathrm{H}\right] \mathrm{dThd},\left[{ }^{3} \mathrm{H}\right] \mathrm{Urd},{ }^{3} \mathrm{H}$-amino acids, or $\left[{ }^{32} \mathrm{P}\right] \mathrm{Pi}$ at a final concentration of 2 to $3 \mu \mathrm{Ci} / \mathrm{ml}$ of labeled precursor. $\left[{ }^{3} \mathrm{H}\right] \mathrm{dThd}$ and $\left[{ }^{3} \mathrm{H}\right] \mathrm{Urd}$ were diluted with unlabeled nucleoside to give a final concentration of 3 to $6 \mu \mathrm{M}$ (noninhibitory during the course of the assay). At the end of the incubation period, cells were harvested onto filter paper using a Skatron cell harvester (Skatron, Inc., Sterling, VA) and washed free of unincorporated label with sequential washes of 5\% trichloroacetic acid and water. Radioactivity was quantitated using a liquid scintillation spectrometer. Cultures labeled with $\left[{ }^{32} \mathrm{P}\right] \mathrm{Pi}$ were incubated with $1 \mathrm{~N} \mathrm{NaOH}$ for $2 \mathrm{~h}$ at $37^{\circ} \mathrm{C}$ prior to harvesting to hydrolyze RNA.

\section{Separation of cellular DNA and RNA by isopycnic centrifugation in $\mathrm{Cs}_{2} \mathrm{SO}_{4}$}

The method for $\mathrm{Cs}_{2} \mathrm{SO}_{4}$ isopycnic centrifugation was a modification of the procedure described by Stenberg et al. (1988). $\left[{ }^{32} \mathrm{P}\right] \mathrm{Pi}$ at a final concentration of 3 $\mu \mathrm{Ci} / \mathrm{ml}$ was added to untreated and drug-treated $\mathrm{KB}$ cell monolayers to label cellular DNA and RNA. Following an incubation period of $24 \mathrm{~h}$, cells were harvested by adding $0.25 \mathrm{M}$ EDTA ( $\mathrm{pH}=8.0$ ) and the cell suspensions were centrifuged at 
low speed for $5 \mathrm{~min}$ at $5^{\circ} \mathrm{C}$. The resulting pellets were stored at $-20^{\circ} \mathrm{C}$ until further analysis. The pellets were thawed, suspended in $1.2 \mathrm{ml}$ of TES buffer $(30 \mathrm{mM}$ Tris, $5 \mathrm{mM}$ EDTA, $50 \mathrm{mM} \mathrm{NaCl}, \mathrm{pH}=8.0$ ) and vortexed. Subsequent isolation of nucleic acids was accomplished by adding $1.2 \mathrm{ml}$ of a solution of pronase $(4 \mathrm{mg} / \mathrm{ml})$ in TES buffer containing $2 \%$ sarkosyl to the pellet suspension and incubating for 20 min at $37^{\circ} \mathrm{C}$. One $\mathrm{ml}$ of the resulting suspension was mixed with $9 \mathrm{ml}$ of $1.93 \mathrm{M}$ $\mathrm{Cs}_{2} \mathrm{SO}_{4}$ in TES buffer $(0.8 \mathrm{~g} / \mathrm{ml})$ and centrifuged at $120000 \times \mathrm{g}$ for $66 \mathrm{~h}$ at $15^{\circ} \mathrm{C}$ in a Beckman L3-50 ultracentrifuge using a Ti 70.1 rotor. Samples were collected from the bottom of the centrifuge tubes and $50 \mu \mathrm{l}$ of each fraction was transferred to a well of a 96-well tissue culture plate. The contents of each well were treated with 5\% trichloroacetic acid and then collected onto filter paper using the Skatron cell harvester. The radioactivity of acid-precipitable materials was determined as detailed above.

\section{Cell growth rates}

The growth rates of uninfected $\mathrm{KB}$ and HFF cells were determined as described by Nassiri et al., 1990. Population doubling times were calculated using numbers of cells obtained at 24 and $96 \mathrm{~h}$ after planting.

\section{Plating efficiency}

An additional assay, plating efficiency, was used to confirm and extend results from cell growth experiments. KB and HFF cells were suspended in growth medium and an aliquot containing 500-600 cells was added to a $140 \times 25 \mathrm{~mm}$ petri dish. Growth medium $(40 \mathrm{ml})$ containing selected concentrations of test compounds was added and the cultures were incubated in a humidified atmosphere of $4 \% \mathrm{CO}_{2}-96 \%$ air at $37^{\circ} \mathrm{C}$ for 14 days. Medium was decanted and attached cells were fixed with methanol and stained with $0.1 \%$ crystal violet in $20 \%$ methanol. Macroscopic colonies $>1 \mathrm{~mm}$ in diameter were enumerated.

\section{Flow cytometry}

Cultures of KB cells as well as HFF cells were incubated with or without compound 102. Cell cycle analysis by flow cytometry was accomplished on a EPICS V flow cytometer (Coulter Electronics, Miami, FL) fitted with an argon-ion laser emitting at $488 \mathrm{~nm}(400 \mathrm{~mW})$, a $515-\mathrm{nm}$ long pass filter, $560-\mathrm{nm}$ dichroic filter and $630-\mathrm{nm}$ long pass filter. A minimum of 10000 cells were analyzed for each histogram generated. Details of the methods have been described earlier (Nassiri et al., 1990).

\section{Data analysis}

Dose-response relationships were used to compare drug effects. These were constructed by linearly regressing the percent inhibition of parameters derived in the 
preceding sections against log drug concentrations. The $50 \%$ inhibitory $\left(I_{50}\right)$ concentrations were calculated from the regression lines using the methods described by Goldstein (1964). Dose-response relationships for DNA histograms were evaluated by methods described previously (Drach et al., 1981). Briefly, the total area under the histogram was quantitated and normalized for the number of cells present in each culture.

\section{Results}

\section{Activity against $H C M V$}

The antiviral activity of the acyclic halogenated tubercidin analogs previously described by us as compounds $\mathbf{1 0}, \mathbf{1 1}$, and $\mathbf{1 2}$, but referred to herein as compounds 100, 102 and 104 (Fig. 1), was initially discovered using plaque-reduction assays (Pudlo et al., 1988). Those results showed the compounds were active against HCMV in the micromolar range $\left(I_{50}=16,3.9\right.$ and $24 \mu \mathrm{M}$, respectively). In order to more completely define activity against $\mathrm{HCMV}$, yield (titer) reduction experiments were employed in the current study. Fig. 2 displays results of such experiments and compares the activities of the three compounds to that of acyclovir, a known antiviral nucleoside with the same acyclic sugar. In agreement with our previous results (Pudlo et al., 1988) the acyclic bromotubercidin analog (compound 102) was the most potent of the four agents tested against HCMV. At a concentration of 100 $\mu \mathrm{M}$, compound 102 reduced the virus titer well below $1 \%$ of control. Compound 104 was approximately 5 -fold less potent at this concentration whereas compound 100 and acyclovir were almost 50 times less potent than compound 102. None of the compounds tested, however, was as potent as ganciclovir - another clinically useful antiviral compound possessing a different acyclic sugar. Virus titers were reduced $10^{5}$-fold by $32 \mu \mathrm{M}$ ganciclovir (data not shown).

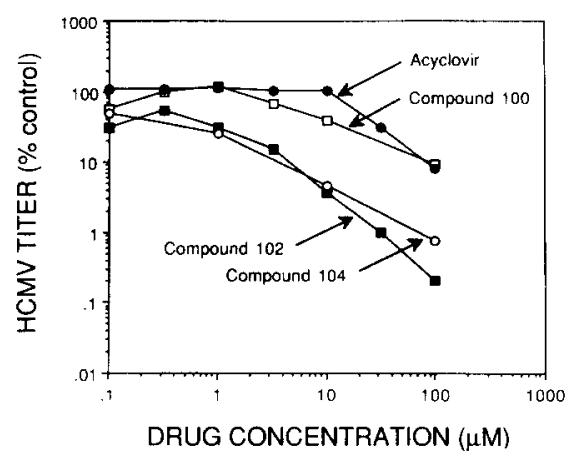

Fig. 2. Effects of acyclic halogenated tubercidin analogs on the replication of HCMV. Subconfluent monolayers of HFF cells were infected with 0.5 PFU per cell of HCMV and incubated in the presence of test compounds for 7 days. Infectious virus was quantitated by plaque assay. Control titers ranged $2.7 \times 10^{4}$ to $5.2 \times 10^{5}$ PFU per ml. 


\section{Inhibition of viral DNA synthesis}

The three acyclic nucleosides and ganciclovir were examined for their inhibitory effect on viral DNA synthesis in HCMV-infected cells by means of DNA-DNA dot blot hybridization. The results are shown in part A of Table 1 . The potency of inhibition of HCMV DNA synthesis by the acyclic compounds was in the same rank order as seen in both plaque and titer reduction assays, namely, the 5- $\mathrm{Br}$ analog $>$ 5-I > 5-Cl. Compound 102 was comparable in activity to ganciclovir in this assay. The $\mathrm{I}_{50}$ concentrations for viral DNA synthesis appeared to be slightly lower than $I_{50}$ concentrations obtained in plaque-reduction assays (Pudlo et al., 1988) suggesting inhibition of viral DNA synthesis is causally related to antiviral activity.

\section{Effects on labeled precursor incorporation in uninfected cells}

When the inhibitory effects of the three acyclic compounds on uninfected cells were measured by visual inspection as part of plaque-reduction assays, compounds 100,102 , and 104 produced virtually no cytopathogenic effects at $100 \mu \mathrm{M}$ (Pudlo et al., 1988). In contrast, when the effects of the compounds were measured by the uptake of labeled precursors, inhibition was noted. Parts B and C of Table 1 show that all three compounds but not ganciclovir inhibited cellular DNA synthesis (measured by $\left[{ }^{3} \mathrm{H}\right] \mathrm{dTh}$ uptake) in both $\mathrm{KB}$ and HFF cells. The $\mathrm{I}_{50}$ concentrations ranged from 0.38 to $2.9 \mu \mathrm{M}$ in $\mathrm{KB}$ cells and 0.09 to $3.4 \mu \mathrm{M}$ in HFF cells. In con-

TABLE 1

Effect of acyclic halogenated tubercidin analogs on HCMV DNA synthesis and labeled precursor incorporation in uninfected cells ${ }^{\mathrm{a}}$

\begin{tabular}{|c|c|c|c|c|}
\hline \multirow[t]{2}{*}{ Precursor } & \multicolumn{4}{|c|}{$\mathrm{I}_{50}$ concentration $(\mu \mathrm{M})$ for compound } \\
\hline & 100 & 102 & 104 & Ganciclovir \\
\hline \multicolumn{5}{|l|}{ A. HCMV } \\
\hline DNA Synthesis & 4.3 & 1.6 & 4.6 & 1.8 \\
\hline \multicolumn{5}{|l|}{ B. KB Cells } \\
\hline$\left[{ }^{3} \mathrm{H}\right] \mathrm{dThd}$ & 1.1 & 0.38 & 2.9 & 354 \\
\hline$\left[{ }^{3} \mathrm{H}\right] \mathrm{Urd}$ & 284 & 771 & $>100^{b}$ & $>1000$ \\
\hline${ }^{3} \mathrm{H}$-amino acids & 502 & 626 & $>100$ & $>1000$ \\
\hline$\left[{ }^{32} \mathrm{P}\right] \mathrm{Pi}$ & 30 & 11 & 65 & 591 \\
\hline \multicolumn{5}{|l|}{ C. HFF Cells } \\
\hline$\left[{ }^{3} \mathrm{H}\right]$ Thd & 0.09 & 0.09 & 3.4 & $\mathrm{ND}^{c}$ \\
\hline$\left[{ }^{3} \mathrm{H}\right] \mathrm{Urd}$ & 139 & 150 & 80 & ND \\
\hline${ }^{3} \mathrm{H}$-amino acids & 151 & 365 & 239 & ND \\
\hline
\end{tabular}

${ }^{a}$ Incorporation of labeled precursors into acid-precipitable material in uninfected cells was determined as described in the text. HCMV DNA synthesis was measured by DNA-DNA hybridization. Each $\mathrm{I}_{50}$ concentration was determined from a dose-response curve constructed using data from at least two seperate experiments.

${ }^{b}>$ indicates $I_{50}$ concentration was not reached at highest (noted) concentration tested.

${ }^{\mathrm{c}} \mathrm{ND}$, not determined. 
trast, the use of $\left.{ }^{32} \mathrm{P}\right] \mathrm{Pi}$ to label DNA revealed less inhibition than was observed by labeling with $\left[{ }^{3} \mathrm{H}\right] \mathrm{dTh}$. Differences of 22 - to 30 -fold were noted for the three acyclic compounds but less than a two-fold difference was observed with ganciclovir. None of the compounds exhibited significant inhibitory effects on the incorporation of $\left[{ }^{3} \mathrm{H}\right] \mathrm{Urd}$ into RNA or ${ }^{3} \mathrm{H}$-amino acids into protein.

To confirm the results of $\left[{ }^{3} \mathrm{H}\right]$ Urd labeling and to ensure that the procedure for labeling with $\left[{ }^{32} \mathrm{P}\right] \mathrm{Pi}$ and subsequent hydrolysis of RNA had labeled only DNA, ${ }^{32} \mathrm{P}$-labeled RNA and DNA isolated from drug-treated cultures were separated on $\mathrm{Cs}_{2} \mathrm{SO}_{4}$ gradients. Fig. 3 shows the $\mathrm{Cs}_{2} \mathrm{SO}_{4}$ isopycnic profiles of nucleic acids from untreated $\mathrm{KB}$ cells and cells treated with $10 \mu \mathrm{M}$ of compound 102. As seen from the profiles, the amount of radioactivity incorporated into RNA was equal in both untreated and treated cells, showing no inhibition of RNA synthesis occurred. In contrast, the amount of radioactivity incorporated into DNA in treated cultures suggested nearly a $45 \%$ reduction in cellular DNA synthesis. At concentrations of 3.2 and $32 \mu \mathrm{M}$ of the same compound, $33 \%$ and $83 \%$ reductions in the synthesis of DNA were noted respectively (profiles not shown). At $32 \mu \mathrm{M}$, a $48 \%$ reduction in RNA synthesis occurred.

Dose-response relationships for the inhibition of DNA synthesis were constructed from the $\mathrm{Cs}_{2} \mathrm{SO}_{4}$ gradient profiles and an $\mathrm{I}_{50}$ concentration of $7.2 \mu \mathrm{M}$ was interpolated. This value is consistent with that obtained by ${ }^{32} \mathrm{P}$-labeling and hydrolysis ( $11 \mu \mathrm{M}$, Table 1$)$ but is inconsistent with that attained by $\left[{ }^{3} \mathrm{H}\right] \mathrm{dThd}$ incorporation $(0.38 \mu \mathrm{M})$.

\section{Flow cytometry}

Because of the different results obtained by incorporation of $\left[{ }^{3} \mathrm{H}\right] \mathrm{dTh}$ and $\left[{ }^{32} \mathrm{P}\right] \mathrm{Pi}$, we further examined the effect of compound 102 on DNA synthesis in

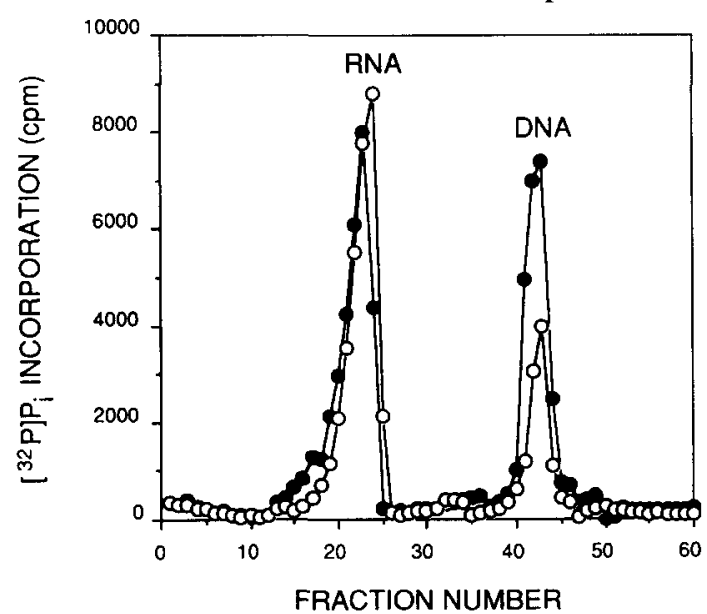

Fig. 3. Effect of compound 102 on incorporation of $\left[{ }^{32} \mathrm{P}\right] \mathrm{H}_{3} \mathrm{PO}_{4}$ into $\mathrm{RNA}$ and DNA of $\mathrm{KB}$ cells. Cultures of $\mathrm{KB}$ cells were labeled with $3 \mu \mathrm{Ci} / \mathrm{ml}\left[{ }^{32} \mathrm{P}\right] \mathrm{Pi}$ and treated with $(O)$ or without $(O) 10 \mu \mathrm{M}$ compound 102 . Following a 24-h incubation, cells were harvested and nucleic acids separated by isopycnic centrifugation in $\mathrm{Cs}_{2} \mathrm{SO}_{4}$ gradients. 
uninfected $\mathrm{KB}$ cells by measuring fluorescence from intercalated propidium diiodide using a flow cytometer. DNA histograms comparing untreated cultures and cultures treated with $10 \mu \mathrm{M}$ compound 102 are presented in Fig. 4. Results show that drug-treated cultures exhibit the following: a marked decrease of cells in the $G_{0} / G_{1}$ phase of the cell cycle, a marked accumulation of cells in mid-S phase, and a diminished population of cells in the $\mathrm{G}_{2} / \mathrm{M}$ population fraction. Similar results were obtained with HFF cells (data not shown).

Similar experiments were performed with other concentrations of compound 102 to construct a dose-response relationship for the effect on total DNA content as measured by propidium diiodide fluorescence. An $\mathrm{I}_{50}$ concentration of approximately $0.9 \mu \mathrm{M}$ was obtained. This measurement agrees more closely with the results of $\left[{ }^{3} \mathrm{H}\right] \mathrm{dTh}$ incorporation than of $\left[{ }^{32} \mathrm{P}\right] \mathrm{Pi}$ incorporation.

\section{Cell growth and population doubling time}

Because DNA histograms showed definite S-phase blockage of DNA synthesis the effects of compounds on suppression of cell growth in uninfected KB and HFF cells were investigated. Growth curves were generated in the presence and absence of test compounds. During a typical 70-h incubation, untreated KB cells underwent three population doublings. Concentrations up to $10 \mu \mathrm{M}$ compound 104 and 100 $\mu \mathrm{M}$ compound 100 only slightly increased the doubling time of $\mathrm{KB}$ cells to $27-30$ h (Table 2). Compound 102 was significantly more potent. A $10-\mu \mathrm{M}$ concentration of compound 102 caused a pronounced prolongation of cell doubling time to $84 \mathrm{~h}$. The effect of these compounds on HFF cells was slightly less pronounced than their effect on $\mathrm{KB}$ cells (data not shown).

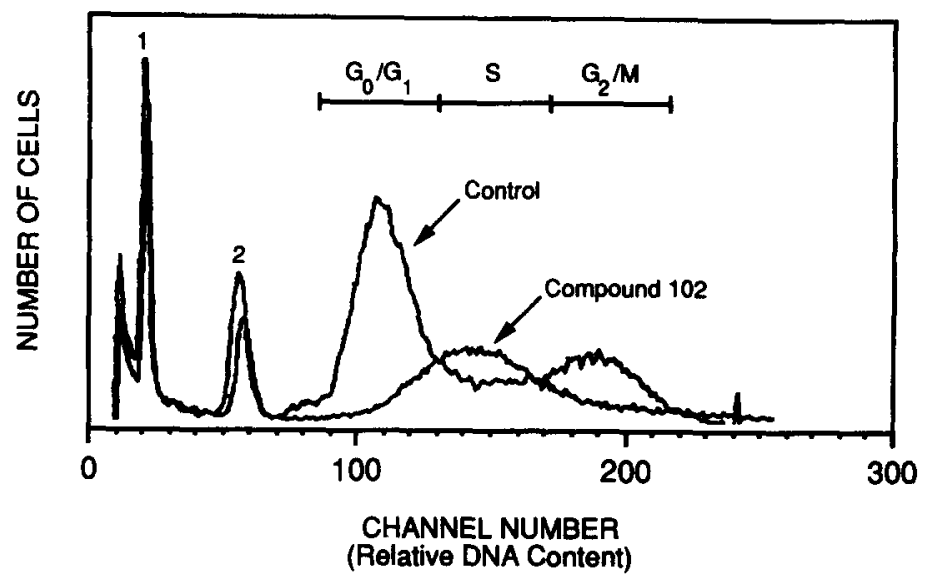

Fig. 4. DNA histograms illustrating nonparametric comparisons of untreated $\mathrm{KB}$ cells and $\mathrm{KB}$ cells treated for $24 \mathrm{~h}$ with $10 \mu \mathrm{M}$ compound 102 and then analyzed by flow cytometry. Each histogram is the average of five individual cultures. Peaks 1 and 2 represent nuclei from chicken erythrocytes and human lymphocytes, respectively. The inserted time line details the stages of the cell growth cycle which correspond to segments of the control DNA histogram. 
TABLE 2

Effect of acyclic halogenated tubercidin analogs on the population doubling time (PDT) of KB cells

\begin{tabular}{llll}
\hline $\begin{array}{l}\text { Drug } \\
\text { concentration } \\
(\mu \mathrm{M})\end{array}$ & \multicolumn{2}{l}{ PDT $(\mathrm{h})$ in the presence of compound } & 104 \\
\cline { 2 - 3 } & 100 & 102 & 23 \\
\hline 0 & 23 & 23 & 26 \\
0.1 & $N^{\mathrm{a}}$ & 30 & 25 \\
1 & 25 & 43 & 30 \\
10 & 25 & 84 & $\mathrm{ND}$ \\
\hline
\end{tabular}

ND, not determined.

\section{Plating efficiencies}

The effects of the acyclic compounds on the attachment and colony formation of $\mathrm{KB}$ and HFF cells were determined as a more stringent measure of their effects on uninfected cells. The results of plating efficiency assays are presented in Table 3 as $\mathrm{I}_{50}$ concentrations. Included in the comparison is compound 080 which is the parent compound of the series, unsubstituted in the 5-position. This compound is inactive against HCMV and is non-cytotoxic in other assays (Saxena et al., 1988). In the current study it also did not affect the plating and growth of KB cells (Table 3). In contrast, the halogenated analogs inhibited the capacity of KB cells to attach and form colonies at concentrations similar to those which inhibit $\left[{ }^{3} \mathrm{H}\right] \mathrm{dThd}$ incorporation (see Table 1). Surprisingly, ganciclovir was inhibitory in this assay at concentrations 10-fold less than those required to inhibit labeled precursor incorporation (Table 1). All compounds, including compound 080 and ganciclovir, had more pronounced effects on HFF cells than KB cells. The marked effect of compound 080 showed that HFF cells are particularly sensitive to the pyrrolopyrimidine nucleosides. This probably is due in part to the lower cloning efficiency of HFF cells compared to KB cells.

TABLE 3

Effect of acyclic tubercidin analogs on relative plating efficiencies

\begin{tabular}{lll}
\hline Compound & $\mathrm{I}_{50}$ concentration $(\mu \mathrm{M})$ & \\
\cline { 2 - 3 } & KB cells & HFF cells \\
\hline 080 & $>320^{\mathrm{a}}$ & 18 \\
100 & 3.9 & 0.17 \\
102 & 0.25 & 0.08 \\
104 & 1.2 & 0.11 \\
Ganciclovir & 51 & 35 \\
\hline
\end{tabular}

"Less than $20 \%$ inhibition observed at highest concentration tested $(320 \mu \mathrm{M})$. 
TABLE 4

Adenosine antagonism of the effect of acyclic halogenated tubercidin analogs on $\left[{ }^{3} \mathrm{H}\right]$ thymidine incorporation by $\mathrm{KB}$ cells ${ }^{\mathrm{a}}$

\begin{tabular}{lll}
\hline Compound & $\begin{array}{l}\text { Adenosine } \\
\text { concentration }(\mu \mathrm{M})\end{array}$ & $\begin{array}{l}\mathbf{I}_{50} \\
\text { concentration }(\mu \mathrm{M})\end{array}$ \\
\hline 100 & 0 & 0.74 \\
& 3.2 & 1.7 \\
10 & 2.9 \\
32 & $>10^{\mathrm{b}}$ \\
& & \\
102 & 0 & 0.28 \\
& 3.2 & 0.82 \\
& 10 & 1.9 \\
& 50 & 4.5 \\
\hline
\end{tabular}

${ }^{a}$ Incorporation of $\left[{ }^{3} \mathrm{H}\right]$ Thd was performed as described in the text except that $1 \mu \mathrm{g} / \mathrm{ml}$ of deoxycoformycin was added to prevent the deamination of adenosine. Protocols for determining $I_{50}$ concentrations in the presence and absence of adenosine and deoxycoformycin have been detailed elsewhere (Birch et al., 1989). Data are from three separate experiments.

${ }^{\mathrm{b}} \mathrm{I}_{50}$ concentration was not reached at highest concentration $(10 \mu \mathrm{M})$ tested.

Antagonism of effects on $\left[{ }^{3} \mathrm{H}\right]$ thymidine incorporation by adenosine

Previous studies by us (Birch et al., 1989) have shown that the effect of sangivamycin [a pyrrolopyrimidine nucleoside phosphorylated by adenosine kinase (Suhadolnik, 1979)] on $\left[{ }^{3} \mathrm{H}\right] \mathrm{dTh}$ incorporation by uninfected cells is antagonized by adenosine. To explore if effects of the acyclic halogenated tubercidin analogs on $\left[{ }^{3} \mathrm{H}\right] \mathrm{dThd}$ incorporation by $\mathrm{KB}$ cells also might be mediated by adenosine kinase, similar studies with compounds 100 and 102 were performed. Dose-response relationships for inhibition of $\left[{ }^{3} \mathrm{H}\right] \mathrm{dTh}$ incorporation by the two compounds were examined at selected concentrations of adenosine. All concentrations of adenosine from 3.2 to $50 \mu \mathrm{M}$ caused dose-response curves to shift to the right (data not shown). Table 4 presents $I_{50}$ concentrations from these curves and establishes that the activity of both compounds was antagonized by adenosine. These data suggest that antagonism may have occurred at the kinase level.

\section{Discussion}

Our initial testing of acyclic halogenated pyrrolo[2,3- $d]$ pyrimidines showed these compounds were active against HCMV and herpes simplex virus (HSV) type 1 and did not produce visual cytotoxicity in uninfected cells (Pudlo et al., 1988). Subsequent studies (Nassiri et al., 1990) showed, however, that compound 102 inhibited cell growth but did so in a reversible, cytostatic manner. Thus, no visual cytotoxicity was noted earlier (Pudlo et al., 1988) because cell death had not occurred even though cell division was blocked.

The current study was initiated to explore cellular and molecular mechanisms by 
which compound 102 and two closely related analogs produce antiviral and cytostatic activity. Based upon results presented in this report, the biochemical actions of the acyclic halogenated pyrrolopyrimidines appear to be more restricted than the actions of the parent naturally-occurring nucleosides tubercidin, toyocamycin, and sangivamycin (Suhadolnik, 1979; Ritch and Glazer, 1984). These ribosyl pyrrolopyrimidines inhibit virus replication but are highly cytotoxic as well (Turk et al., 1987b). Results with all three acyclic halogenated compounds, but especially results with compound 102 , clearly demonstrate inhibition of both cellular and viral DNA synthesis as primary events. Even though Yang et al. (1990) found evidence for inhibition of protein synthesis in guinea pig CMV-infected cells at high concentrations $(800 \mu \mathrm{M})$ of compound 102 , we found little or no inhibition of RNA or protein synthesis at concentrations (up to $100 \mu \mathrm{M}$ ) which gave good activity against HCMV. These short-term studies $(24 \mathrm{~h})$, however, were not designed to be fully indicative of potential secondary effects accumulating during long-term exposure to the compounds.

The questions of whether inhibition of DNA synthesis is sufficient to account entirely for antiviral activity and whether preferential inhibition of viral DNA synthesis occurs are still not fully answered. Data favoring the interpretation that the compounds have antiviral selectivity include the observation that viral DNA synthesis was inhibited by drug concentrations approximately 10 -fold lower than required for inhibition of cellular DNA synthesis as measured by $\left[{ }^{32} \mathrm{P}\right] \mathrm{Pi}$ incorporation (Table 1 and Fig. 3). In addition, concentrations of compounds 102 and 104 (e.g. $10 \mu \mathrm{M}$ ) which inhibited HCMV replication by $>95 \%$ (Fig. 2) produced only slight (compound 104) or 3-fold (compound 102) increases in population doubling times of uninfected cells (Table 2). Further evidence for viral specificity are data by Hu and Hsiung (1989a) which show a marked multiplicity of infection effect for the activity of compound 102 against guinea pig lymphotropic herpesvirus (GPHLV). Arguing against the theory of antiviral selectivity are data obtained by $\left[{ }^{3} \mathrm{H}\right] \mathrm{dThd}$ incorporation (Table 1), flow cytometry (Fig. 4) and plating efficiency (Table 3). Cellular DNA synthesis as measured by these two means and plating efficiency were more sensitive to inhibition by the compounds than was viral DNA synthesis.

Clearly, more investigation is needed to reconcile these disparate results. The lack of agreement of the isotopic methods for quantitating DNA synthesis is particularly puzzling. Previously we had observed a similar phenomenon with ribavirin wherein $\left[{ }^{3} \mathrm{H}\right] \mathrm{dThd}$ incorporation was more sensitive to inhibition than was $\left[{ }^{32} \mathrm{P}\right] \mathrm{Pi}$ incorporation (Drach et al., 1981). In that case, however, results from flow cytometry correlated better with the $\left[{ }^{32} \mathrm{P}\right] \mathrm{Pi}$ data than the $\left[{ }^{3} \mathrm{H}\right] \mathrm{dTh}$ Thesults. It was discovered that $\left[{ }^{3} \mathrm{H}\right] \mathrm{dThd}$ incorporation greatly overestimated inhibition of DNA synthesis due to drug-induced perturbations in labeled thymidine nucleotide pools. A similar explanation does not appear to apply in the present case and it is difficult to envision a mechanism whereby these compounds could increase the specific activity of the $\left[{ }^{32} \mathrm{P}\right]$-labeled dNTP pools and effect an overestimation of inhibition of DNA replication.

Enzymatic mechanisms by which these compounds act have not been explored 
directly. Our data and that of others do, nonetheless, suggest biochemical bases for the action and possible antiviral selectivity of the compounds. Based on the facts that DNA but not RNA or protein synthesis is inhibited and that related nucleoside analogs such as acyclovir must be phosphorylated to inhibit DNA synthesis (Drach, 1984), we assume that the acyclic compounds also must be phosphorylated. For the reasons that HCMV does not encode any currently known nucleoside kinases (Kit, 1979), the activity of compound 102 against HSV type 1 is cell-line dependent (Hu and Hsiung, 1989b) and the inhibition of $\left[{ }^{3} \mathrm{H}\right] \mathrm{dTh}$ incorporation by uninfected cells is antagonized by adenosine (Table 4), we speculate that this compound is activated by cellular adenosine kinase. Despite the possibility that HCMV-encoded nucleoside kinases may not exist, it has been demonstrated that cellular nucleoside kinases are stimulated during HCMV infection (Estes and Huang, 1977; Freitos et al., 1985). This could lead to preferential phosphorylation of the acyclic halogenated tubercidin analogs by virus-infected cells and confer some degree of antiviral specificity.

The site of action of putative nucleoside phosphates is even more speculative. Labeled precursor incorporation, DNA-DNA hybridization and flow cytometry data all show inhibition of DNA synthesis. The most logical loci of inhibition are DNA polymerase and ribonucleotide reductase. Indeed, the 5 -triphosphate of the arabinosyl analog of tubercidin is an inhibitor of cellular and HSV-encoded DNA polymerases (Turk et al., 1987a) as well as HCMV-encoded DNA polymerase (our unpublished data). Furthermore, the need to keep compound 102 in contact with cells for it to express antiviral (Yang et al., 1990) and cytostatic activity (Nassiri et al.,1990) plus the fact that these activities are reversed by drug removal, suggest the following: incorporation into DNA and blockage of chain elongation are not likely mechanisms of DNA synthesis inhibition or incorporated molecules are readily removed from DNA by repair mechanisms.

The $5^{\prime}$-diphosphates of tubercidin and toyocamycin have been reported to be substrates (and therefore potential inhibitors) of ribonucleotide reductase derived from E. coli (Chassey and Suhadolnik, 1968). The accumulation of cells in mid Sphase by compound 102 is similar to results seen when cells are treated with high concentrations of dThd (our unpublished results), a condition wherein reductase is inhibited via feedback regulation by dTTP (Nutter and Cheng, 1984). In contrast, cells treated with hydroxyurea (a more potent inhibitor of ribonucleotide reductase) accumulate at the $\mathrm{G}_{1} / \mathrm{S}$ border (Bhuyan and Groppi, 1989), suggesting that compound 102 is not an exceptionally potent inhibitor of ribonucleotide reductase. Firm data to resolve possibilities such as these await enzymatic studies to more fully understand the mode-of-action of these novel compounds.

\section{Acknowledgements}

The authors are indebted to Deborah K. Wasik and Scott Montgomery for expert preparation of the manuscript. This work was supported with Federal Funds from the Department of Health and Human Services under contracts NO1-AI-42554 and 
NO1-AI-72641. The content of this publication does not necessarily reflect the views or policies of the Department of Health and Human Services, nor does mention of trade names, commercial products, or organizations imply endorsement by the U.S. Government.

\section{References}

Betts, R.F. and Hanshaw J.B. (1977) Cytomegalovirus (CMV) in the compromised host(s). Ann. Rev. Med. 28, 103-110.

Bhuyan, B.K. and Groppi, V.E. (1989) Cell cycle specific inhibitors. Pharmacol. Ther. 42, 307-348

Birch, G.M., Krawczyk, S.H., Townsend, L.B. and Drach, J.C. (1989) Antagonism of the cytotoxic but not antiviral effects of ara-sangivamycin by adenosine. Antimicrob. Agents Chemother. 33, $1606-$ 1608.

Bombi, J.A., Cardesa, A., Llebaria, C., Rives, A., Carreras, E., Grànena, A. and Jimenez de Anta, M.T (1987) Main autopsy findings in bone marrow transplant patients. Arch. Pathol. Lab. Med. 111, 125129.

Chassy, B.M. and Suhadolnik, R.J. (1968) Nucleoside antibiotics. II. Biochemical tools for studying the structural requirements for interaction at the catalytic and regulatory sites of ribonucleotide reductase from Escherichia coli. J. Biol. Chem. 243, 3538-3541.

Colacino, J.M. and Lopez, C. (1983) Efficacy and selectivity of some nucleoside analogs as anti-human cytomegalovirus agents. Antimicrob. Agents Chemother. 24, 505-508.

Collaborative DHPG Treatment Study Group (1986) Treatment of serious cytomegalovirus infection with 9-(1,3-dihydroxy-2-propoxymethyl)guanine in patients with AIDS and other immunodeficiencies. N. Eng. J. Med. 314, 801-805.

Drach, J.C. (1984) Purine nucleoside analogs as antiviral agents. In: E. De Clercq and R.T. Walker (Eds), Targets for the design of antiviral agents, pp. 231-257. Plenum Press, New York.

Drach, J.C., Thomas, M.A., Barnett, J.W., Smith, S.H. and Shipman, C., Jr. (1981) Tritiated thymidine incorporation does not measure DNA synthesis in ribavirin-treated human cells. Science 212, 549 551.

Estes, J.E. and Huang, E.-S. (1977) Stimulation of cellular thymidine kinases by human cytomegalovirus. J. Virol. 24, 13-21.

Field, A.K., Davies, M.E., DeWitt, C., Perry, H.C., Liou, R., Germershausen, J., Karkas, J.D., Ashton, W.T., Johnston, D.B.R. and Tolman, R.L. (1983) 9-\{[2-Hydroxy-1-(hydroxymethyl)ethoxy]methyl guanine: a selective inhibitor of herpes group virus replication. Proc. Natl. Acad. Sci. USA $80,4139-4143$.

Freitos, V.R., Smee, D.F., Chernow, M., Boehme, R. and Matthews, T.R. (1985) Activity of 9-(1,3-dihydroxy-2-propoxymethyl)guanine compared with that of acyclovir against human, monkey, and rodent cytomegaloviruses. Antimicrob. Agents Chemother. 28, 240-245.

Glen, J. (1981) Cytomegalovirus infections following renal transplantation. Rev. Infect. Dis. 3, 11511178 .

Goldstein, A. (1964) Biostatistics, an introductory text. MacMillan, New York, pp. 156-161.

Gupta, P.K., Daunert, S., Nassiri, M.R., Wotring, L.L., Drach, J.C. and Townsend, L.B. (1989a) Synthesis, cytotoxicity and antiviral activity of some acyclic analogues of the pyrrolo[2,3-d]pyrimidine nucleoside antibiotics tubercidin, toyocamycin and sangivanycin. J. Med. Chem. 32, 402-408.

Gupta, P.K., Nassiri, M.R., Coleman, L.A., Wotring, L.L., Drach, J.C. and Townsend, L.B. (1989b) Synthesis, cytotoxicity and antiviral activity of certain 7-[(2-hydroxyethoxy)methyl]pyrrolo[2,3- $d]-$ pyrimidine nucleosides related to toyocamycin and sangivamycin. J. Med. Chem. 32, 1420-1425.

Hayflick, L. (1973) Screening tissue cultures for mycoplasma infections. In: P.F. Kruse, Jr. and M.K. Patterson, Jr. (Eds), Tissue culture: Methods and applications, pp. 722-728. Academic Press Inc., New York.

Hu, J.M. and Hsiung, G.D. (1989a) Activities of two new antiviral agents against guinea pig lympho- 
tropic herpesvirus infection in vitro. Antimicrob. Agents Chemother. 33, 1600-1605.

Hu, J.M. and Hsiung, G.D. (1989b) Evaluation of new antiviral agents: I. In vitro perspectives. Antiviral Res. 11, 217-232.

Jacobson, M.A. and Mills, J. (1988) Serious cytomegalovirus disease in the acquired immunodeficiency syndrome (AIDS). Clinical findings, diagnosis, and treatment. Ann. Intern. Med. 108, 585-594.

Kit, S. (1979) Viral-associated and induced enzymes. Pharmacol. Ther. 4, 501-585.

Klatt, E.C. and Shibata, D. (1988) Cytomegalovirus infection in the acquired immunodeficiency syndrome. Clinical and autopsy findings. Arch. Pathol. Lab. Med. 112, 540-544.

Mar, E.-C., Patel, P.C., Cheng, Y.-C., Fox, J.J., Watanabe, K.A. and Huang, E.-S. (1984) Effects of certain nucleoside analogs on human cytomegalovirus replication in vitro. J. Gen. Virol. 65, 47-53.

Meyers, J.D., Reed, E.C., Shepp, D.H., Thornquist, M., Dandliker, P.S., Vicary, C.A., Fluomey, N., Kirk, L.E., Kersey, J.H., Thomas, E.D. and Balfour, H.H., Jr. (1988) Acyclovir for prevention of cytomegalovirus infection and disease after allogenic marrow transplantation. N. Eng. J. Med. 318, $70-75$.

Morris, D.J. (1988) Antiviral chemotherapy for cytomegalovirus disease. J. Antimicrob. Chemother. 21, 519-522.

Mostoufi-Zadeh, M., Driscoll, S.G., Biano, S.A. and Kundsin, R.B. (1984) Placental evidence of cytomegalovirus infection of the fetus and neonate. Arch. Pathol. Lab. Med. 108, 403-406.

Nassiri, M.R., Hudson, J.L., Pudlo, J.S., Birch, G.M., Townsend, L.B. and Drach, J.C. (1990) Flow cytometric evaluation of the cytotoxicity of novel antiviral compounds. Cytometry $11,411-417$.

Niedt, G.W. and Schinella, R.A. (1985) Acquired immunodeficiency syndrome: Clinicopathologic study of 56 autopsies. Arch. Pathol. Lab. Med. 109, 727-734.

Nutter, L.M. and Cheng Y.-C. (1984) Nature and properties of mammalian ribonucleoside diphosphate reductase. Pharmacol. Ther. 26, 191-207.

O'Donnell, J.J., Jacobson, M.A. and Mills, J. (1987) Development of cytomegalovirus (CMV) retinitis in a patient with AIDS during ganciclovir therapy of CMV colitis. N. Eng. J. Med. 316, 1607-1608.

Plotkin, S.A., Drew, W.L., Felsenstein, D. and Hirsch, M.S. (1985) Sensitivity of clinical isolates of human cytomegalovirus to 9-(1,3-dihydroxy-2-propoxymethyl)guanine. J. Infect. Dis. 152, 833-834.

Pudlo, J.S., Saxena, N.K., Nassiri, M.R., Turk, S.R., Drach, J.C. and Townsend, L.B. (1988) Synthesis and antiviral activity of certain 4- and 4,5-disubstituted 7-[(2-hydroxyethoxy)methyl]pyrrolo[2,3- $d]$ pyrimidines. J. Med. Chem. 31, 2086-2092.

Pudlo, J.S., Nassiri, M.R., Kern, E.R., Wotring, L.L., Drach, J.C. and Townsend, L.B. (1990) Synthesis, antiproliferative, and antiviral activity of certain 4-substituted and 4,5-disubstituted 7-[(1,3-dihydroxy-2-propoxy)methyl]pyrrolo[2,3- $d$ ]pyrimidines. J. Med. Chem. 33, 1984-1992.

Ritch, P.S. and Glazer, R.I. (1984) Pyrrolo[2,3-d]pyrimidine nucleosides. In: R.I. Glazer (Ed), Developments in cancer chemotherapy, pp. 1-33. CRC Press, Inc., Boca Raton, FL.

Rosecan, L.R., Stahl-Bayliss, C.M., Kalman, C.M. and Laskin, O.L. (1986) Antiviral therapy for cytomegalovirus retinitis in AIDS with dihydroxypropoxymethylguanine. Am. J. Opthamol. 101, 405418.

Saxena, N.K., Hagenow, B.M., Genzlinger, G., Turk, S.R., Drach, J.C. and Townsend, L.B. (1988) Synthesis and antiviral activity of certain 4-substituted and 2,4-disubstituted 7-[(2-hydroxyethoxy)methyl]pyrrolo[2,3-d]pyrimidines. J. Med. Chem. 31, 1501-1506.

Shepp, D.H., Dandliker, P.S., De Miranda, P., Burnette, T.C., Cederberg, D.M., Kirk, L.E. and Meyers, J.D. (1985) Activity of 9-[2-hydroxy-1-(hydroxymethyl)-ethoxymethyl]guanine in the treatment of cytomegalovirus pneumonia. Ann. Intern. Med. 103, 368-373.

Shipman, C., Jr. (1969) Evaluation of 4-(2-hydroxyethyl)-1 - piperazineëthanesulfonic acid (HEPES) as a tissue culture buffer. Proc. Soc. Exp. Biol. Med. 130, 305-310.

Skolnik, P.R. and Hirsch, M.S. (1988) Therapy and prevention of cytomegalovirus infections. In: E. DeClercq (Ed), Clinical use of antiviral drugs, pp. 439-449. Martinus Nijhoff Publishing, Norwell, MA.

Stenberg, K., Lundström, M., Olofsson, S. and Datema, R. (1988) Incorporation into nucleic acids of the antiherpes guanosine analog buciclovir, and effects on DNA and protein synthesis. Biochem. Pharmacol. 37, 1925-1931.

Suhadolnik, R.J. (1979) Pyrrolopyrimidine nucleoside analogs. In: R.J. Suhadolnick (Ed), Nucleosides 
as biological probes, pp. 158-169. John Wiley and Sons, Inc., New York.

Turk, S.R., Cook, P.D., Reinke, C.M. and Drach, J.C. (1987a) Inhibition of herpes simplex virus DNA replication by ara-tubercidin. Antiviral Res. 8, 97-102.

Turk, S.R., Shipman, C., Jr., Nassiri, M.R., Genzlinger, G., Townsend, L.B. and Drach, J.C. (1987b) Pyrrolo[2,3-d]pyrimidine nucleosides as inhibitors of human cytomegalovirus. Antimicrob. Agents Chemother. 31, 544-550.

Yang, Z.H., Klein, S. and Hsiung, G.D. (1990) Comparative effects of two nucleosides on the ultrastructure and replication of guinea pig cytomegalovirus in cultured cells. 